\title{
Review
}

\section{An Update of Evaluation of Intravenous Sedation on Diagnostic Spinal Injection Procedures}

Howard S. Smith, MD¹, James Colson MS, MD², and Nalini Sehgal, MD³

From: ${ }^{2}$ Albany Medical College, Albany, NY; ${ }^{2}$ West Virginia University Hospitals,

Morgantown, WV; and ${ }^{3}$ University of Wisconsin School of Medicine and Public Health, Madison, WI.

Dr. Smith is Professor and Director of Pain Management for Albany Medical College, Department of Anesthesiology,

Albany, NY. Dr. Colson

is Associate Professor of Anesthesiology, Department of Anesthesiology, Pain Medicine Service, West Virginia University Hospitals, Morgantown, WV. Dr. Sehgal is Associate Professor and Director, Interventional

Pain Management, Pain

Medicine Fellowship Program; and Director of the Department of Orthopedics \& Rehabilitation, University of Wisconsin School of Medicine \& Public Health, Madison, WI.

Address correspondence: Howard Smith, M.D.

47 New Scotland Avenue Albany, NY 12208

E-mail: smithh@mail.amc.edu

Disclaimer: There was no external funding in the preparation of this manuscript.

Conflict of interest: None.

Manuscript received: 09-12-2012 Accepted for publication: 02/20/2013

Free full manuscript: www.painphysicianjournal.com
Background: Intravenous (IV) sedation analgesia is often employed in patients with chronic spinal pain undergoing diagnostic spinal injection procedures. The drugs used for intravenous sedation analgesia produce varying degrees of sedation, amnesia, anxiolysis, muscle relaxation, and analgesia. The very nature of these pharmacologic effects in altering the patient's level of consciousness, awareness, or response to a particular diagnostic stimulus invokes a sense of uncertainty about the results or response obtained from the diagnostic procedure. There is an ongoing controversy regarding the validity of controlled diagnostic blocks due to variability in sensitivity, specificity, and accuracy. Moreover, there is no consensus with regards to the use of sedation analgesic measures prior to controlled diagnostic blocks and their influence on the accuracy and validity of a diagnosis.

Objective: To assess and update the clinically significant effects sedation analgesia procedures have on the diagnostic accuracy and validity of interventional spinal techniques.

Methods: A comprehensive literature search using PubMed, EMBASE, and Cochrane Library review databases up to September 2012 was performed. The search included systematic and narrative review articles, prospective and retrospective studies, as well as cross-referencing of bibliographies from notable primary and review articles and abstracts from scientific meetings and peer-reviewed non-indexed journals. The search emphasized the effects of sedation analgesia on diagnostic spinal interventions.

Conclusion: Based on a review of the available evidence, it appears that the administration of mild to moderate sedation does not confound the results or diagnostic validity of spinal injection procedures. Specifically, immediate pain relief after cervical and lumbar facet joint controlled nerve blocks is not enhanced by IV sedation with midazolam or fentanyl. This is especially true if stringent outcome criteria are employed, such as at least $75 \%$ pain relief combined with an increase in range of motion for pain limited movements.

Key words: Conscious sedation, procedural sedation, intravenous sedation, analgesia, hypnotics, sedatives, anxiolytics, opioids, chronic spinal pain, spinal injections, epidural injections, controlled diagnostic nerve blocks, zygapophyseal or facet joint blocks, selective nerve root blocks, provocation discography, sacroiliac joint injections, outcomes

Pain Physician 2013; 16:-SE217-SE228
D

rocedural sedation analgesia (PSA) is the use of anxiolytic, sedative, hypnotic, analgesic, and/or dissociative medication(s) to attenuate anxiety, pain, and/or motion. These agents are administered in order to facilitate amnesia or decrease awareness and/or increase patient comfort and safety during a diagnostic or therapeutic procedure (1-4). PSA is administered worldwide by a diverse group of practitioners to patients of all ages in a variety of clinical settings, both inside and outside the 
operating room (4). Practice guidelines for sedation and analgesia may vary in different regions of the world (5). The American Society of Anesthesiologists (ASA) has developed such guidelines for use by physicians who are not anesthesiologists. The society considers sedation to be a continuum, and defines 3 levels of sedation: minimal, moderate, and deep (Table 1). Minimal sedation provides a drug-induced state of anxiolysis during which patients respond normally to verbal commands. Moderate sedation analgesia, or conscious sedation, is a drug-induced depression of consciousness during which patients respond purposefully to verbal commands when aroused by the sound of a voice or light tactile stimulation. No interventions are required to maintain a patient airway, during conscious sedation. Deep sedation or analgesia is a drug-induced depression of consciousness during which patients cannot be easily aroused but respond purposefully after the administration of repeated or painful stimulation.

Table 1. Description of levels of sedation.

\begin{tabular}{|l|}
\hline Minimal sedation \\
Patient is in drug-induced state of anxiolysis \\
Patient responds normally to verbal commands \\
\hline Conscious sedation \\
Patient has drug-induced depression of consciousness \\
Patient responds purposefully to voice or tactile stimulation \\
No interventions are needed to maintain a patient airway should \\
\hline Deep sedation \\
Patient has drug-induced depression of consciousness \\
Patient cannot be easily aroused \\
Patient responds purposefully after repeated or painful stimulation \\
Ventilatory function may be impaired
\end{tabular}

Source: Jones DR, et al. Videos in clinical medicine. Conscious sedation for minor procedures in adults. N Engl J Med 2011; 364:e54 (5).
Ventilatory function may be impaired during deep sedation or analgesia. Certain invasive or painful procedures require this level of sedation (5).

The drug classes utilized for anxiolysis and analgesia include benzodiazepines, opioids, and other agents (6). Drugs within this class possess varying degrees of pharmacologic potential to produce sedation, amnesia, anxiolysis, muscle relaxation, and analgesia. The very nature of these pharmacologic effects in altering the patient's level of consciousness, awareness, or response to a particular diagnostic stimulus invokes a sense of uncertainty about the results or response obtained from the diagnostic procedure. Table 2 illustrates the spectrum of pharmacologic effects exhibited by the various drugs typically used for PSA (7). Midazolam and fentanyl are more frequently used intravenous (IV) drugs for intraoperative sedation and analgesia due to the short duration of action combined with rapid onset of action. Midazolam is a short-acting benzodiazepine with central nervous system (CNS) depressant activity. The CNS depressant effects of midazolam depend on the dose administered, the route of administration, and the presence or absence of other medications with CNS depressant activity. Midazolam is 3 to 4 times more potent than diazepam. Fentanyl is an opioid analgesic. A dose of $100 \mathrm{mcg}$ or $0.1 \mathrm{mg}$ or $2 \mathrm{~mL}$ is approximately equivalent in analgesic activity to $10 \mathrm{mg}$ of morphine or 75 mg of meperidine. When given intravenously, fentanyl has an almost immediate onset of action. Propofol is another drug commonly used to provide IV sedation. Compared to IV midazolam, it provides statistically significant faster onset of sedation scores, lower mean anxiety scores, and a more rapid recovery with less impairment of recall (8).

Table 2. Comparative spectrum of pharmacologic effects.

\begin{tabular}{|l|c|c|c|c|c|c|c|}
\hline \hline Drug & Anxiolysis* & Sedation & Hypnosis & Analgesia & Amnesia & Anesthesia & Dependency \\
\hline Methohexital & 0 & + & + & 0 & + & + & + \\
\hline Diazepam & + & + & + & 0 & + & + & + \\
\hline Midazolam & + & + & + & 0 & + & + & + \\
\hline Propofol & 0 & + & + & 0 & + & + & + \\
\hline Ketamine & 0 & 0 & 0 & + & + & $+/ \mathrm{D}$ & 0 \\
\hline Fentanyl & 0 & + & + & + & 0 & + & + \\
\hline Remifentanil & 0 & + & + & + & 0 & + & + \\
\hline Dexmedetomidine & 0 & + & + & + & + & S & $0 / \mathrm{A}$ \\
\hline
\end{tabular}

Key: * Possessing receptor specificity for effect; $+=$ Produces effect; $0=$ No effect; $S=$ Anesthetic-sparing effects; A $=$ Attenuates withdrawal symptoms from barbiturates, benzodiazepines, and opioids; $\mathrm{D}=$ Dissociative anesthetic state. 
The most serious complications of conscious sedation are respiratory and cardiovascular depression, which occurs when a patient becomes deeply sedated. Because respiratory and cardiovascular compromise can lead to death, it is vitally important to 1) obtain written consent from the patient, 2) ensure adequate preparation and careful monitoring, and 3) have qualified personnel administer it (9).

The terminology and definitions for sedation related adverse effects were developed by The World Society of Intravenous Anaesthesia (SIVA) International Sedation Task Force (ISTF), after considering and incorporating elements from Institute of Medicine (IOM) (10), World Health Organization (WHO) (11), European Medicines Agency (EMA) (12,13), and United States Food and Drug Administration (FDA) (14) definitions. The ISTF is comprised of 26 physicians from 10 specialties and 11 countries with clinical expertise, a research commitment to the sedation of adults and children, or both. ISTF defines sedation-related adverse effects as: "Unexpected and undesirable response(s) to medication(s) and medical intervention used to facilitate procedural sedation and analgesia that threaten or cause patient injury or discomfort" (4). The Task Force has developed an Adverse Effect Sedation Outcome tool, configured in a check box form, and suitable for use on a web page or paper document, or as part of an electronic medical record. According to this tool, each adverse effect is characterized across 3 domains: description, intervention, and outcome. The specific features within each domain define the severity or clinical importance of the adverse effect: sentinel, moderate, minor, or minimal. Sentinel adverse effects are the most serious and represent those critical enough to pose a real or major imminent risk of patient injury. Once recognized, they warrant immediate and aggressive rescue interventions. Although there are no specific descriptions that alone define a moderate adverse effect, adverse effects are labeled moderate only if they are associated with a moderate intervention or outcome, Minor adverse effects are those encountered periodically in most sedation settings that pose little threat or danger of permanent harm to the patient, given appropriate sedation care, provider skills, and monitoring. Minimal adverse effects are those that alone present no danger of permanent harm to the patient (4). The Adverse Effect Sedation Outcome Tool has not yet been validated in interventional pain management settings.

\subsection{Indications for Procedural Sedation Analgesia}

IV sedation analgesia is inconsistently employed across interventional pain settings. In one survey of pain practices, $46 \%$ of respondents employed IV sedation for lumbar epidural steroid injections and 53\% used it for cervical epidural steroid injections (15). Most practice guidelines discourage the routine use of sedation for interventional pain procedures. There are, however, patients who are unable to cooperate with the procedure for various reasons and for whom sedation may be indicated to control patient anxiety or apprehension and allow for safe and satisfactory conduct of the procedure/intervention. In these instances, providing appropriate sedation goes beyond being humane; it is required in order to perform the procedure safely and effectively. It has been shown that the preprocedural anxiety level correlates with the postprocedural level of patient comfort. One study compared the anxiolytic effect of midazolam and droperidol, administered prior to epidural catheterization, on postprocedural memories and comfort level between 12 and 20 hours and showed that patients receiving midazolam reported significantly less pain and anxiety (16).

Every possible effort should be made to allay the anxiety and apprehension of the patient before a decision is made to employ IV sedation. The indications and justification for sedation must be clearly documented. It is recommended that the patient must remain sufficiently alert and awake to report any unexpected sensations that may warn of an impending complication. At no time, and under no circumstance should the patient be deeply sedated for the spinal injection procedure. This is even more important for diagnostic procedures such as discography, when the patient may need to describe the pain provocation response or need to be awake and mobile immediately after the procedure to assess the analgesic response. For certain therapeutic procedures, the urge to use sedation analgesia to the extent of producing a deep level of conscious sedation should be tempered, as the risks far exceed the potential benefit. Rathmell et al (17) examined the ASA closed claims database between 2005 and 2008, and compared claims arising from cervical pain procedures with all other chronic pain claims. Claims related to cervical interventions represented $22 \%$ of chronic pain treatment claims. Of the claims involving cervical procedures, 59\% had traumatic spinal cord damage. Furthermore, spinal cord injuries were more common 
in patients who received sedation or anesthesia (17). Hence, the need for sedation analgesia must be carefully evaluated. When these techniques are employed, they must be tailored to the comfort and reassurance level of an individual patient, without impairing the accuracy and validity of the diagnostic test.

\subsection{Spinal Interventional Techniques and Procedural Sedation Amalgesia}

Multiple evaluations in interventional pain management describe patients with chronic pain and psychiatric comorbidity who have also been exposed to opioid analgesics (18-36). Among chronic pain disorders, the majority of problems stem from pain arising from various structures of the spine (28). In most of these patients, the source of pain or the structure causing pain cannot be identified by standard diagnostic methods, i.e., history and physical examination, laboratory tests, imaging studies, electrophysiologic studies, or histopathology. Because there is no known biomarker for pain, physicians employ anesthetic blocks of the target structure (joint, nerve) in a controlled manner to identify the structure/s causing pain (28-36). Some of the commonly performed diagnostic interventional techniques include selective nerve root injections, facet joint nerve blocks, discography, and sacroiliac joint injections. In patients with chronic low back pain, controlled blocks have demonstrated that the prevalence of facet joint pain is $25 \%$ to $45 \%$ (32), discogenic pain is $26 \%$ to $42 \%$ (36), and sacroiliac joint pain is $10 \%$ to $62 \%$ (35). Similarly, in patients with chronic neck pain, facet joint pain occurs in $36 \%$ to $60 \%$ (33) and discogenic pain in $16 \%$ to $53 \%$ of patients (31). Nearly $34 \%$ to $48 \%$ of patients with chronic thoracic pain have facet joint pain (34).

When associated with diagnostic injections, the placebo effect may result in false positive rates. In multiple studies, false positive rates for controlled and uncontrolled diagnostic blocks have been estimated to range from $27 \%$ to $63 \%$ for cervical facet joint nerve blocks (33), $42 \%$ to $58 \%$ for thoracic facet joint nerve blocks (34), $17 \%$ to $50 \%$ for lumbar facet joint nerve blocks (32), and $20 \%$ for sacroiliac joints injections (35). Accordingly, Carragee et al (37-40), and others (41-44) have questioned the validity of precision diagnostic blocks. Some of the plausible explanations given for these false-positive responses include use of IV sedation, placebo response to diagnostic injections, liberal use of local anesthetic to infiltrate superficial soft tissues, and the spread of injectate beyond the target structure to anesthetize adjacent structures (41-44).
Cohen and Raja (41) described that both opioids and sedatives, such as midazolam, can lead to false-positive responses by producing general analgesia and/or muscle relaxing properties that interfere with analgesic responses of controlled diagnostic blocks. However, Frölich et al (45), in a recent evaluation assessing the effect of sedation on pain perception, showed that in fact, sedation may increase pain perception. They also showed that the effect of sedation on pain perception is agent- and pain type-specific. In this assessment of 83 healthy volunteers randomly assigned to receive one of 3 sedative drugs, which included midazolam, propofol, or dexmedetomidine, midazolam increased cold, heat, and electrical pain perception significantly; propofol reduced ischemic pain; and dexmedetomidine reduced both cold and ischemic pain significantly. Consequently, midazolam, most commonly utilized as a sedative for interventional pain procedures, does not demonstrate any pain relieving effect, but does increase pain perception. On the other hand, Manchikanti et al (46-49) found that sedation with midazolam exerts minimal effect on the diagnostic accuracy of cervical and lumbar facet joint controlled blocks. The value and validity of diagnostic facet joint blocks (50-53) and accuracy also have been exemplified by therapeutic interventions (54-58).

Psychological factors such as patient mood and motivation to get well can bias patient response., In some cases, the drugs used may interfere with the interpretation of the analgesic response and confound the results of diagnostic blocks. Psychiatric comorbidity such as depression, anxiety, and excessive somatic symptoms are known to actively contribute to the perception of pain (18-24,59-68). Clinically, a diagnosis of depression correlates with increased pain (66-68) and anxiety decreases a patient's pain threshold and tolerance (59). In chronic pain patients, the prevalence of current major depression and anxiety ranges from $15 \%$ to $59 \%$, and is significantly higher than the rate of $5 \%$ to $10 \%$ in persons without pain in the general population $(21-23,59)$. One study showed that preprocedural anxiety levels are predictive of verbal pain intensity ratings following a clinical pain stimulus $(20)$. Manchikanti et al $(19,24)$ evaluated the effect of depression and anxiety on the diagnostic validity of disc and facet joint injections in chronic pain patients and found that these variables did not significantly influence false positive rates. They also studied the effect of prior exposure to opioids (18) on diagnostic blocks and found no significant effect on the diagnostic validity of controlled comparative local 
anesthetic blocks in patients with chronic spinal pain. The role of the placebo effect has been extensively discussed and its role in diagnostic blocks is undetermined (69-118). Local anesthetic blocks have been shown to modulate pain responses (102). However, nocebo effects are not well recognized $(77,98,103-107)$. The role of local anesthetic also has been debated and misinterpreted (108-134). Local anesthetics have been demonstrated to provide long-term relief $(54,57,58,135-166)$.

At this time, the issue of providing procedural sedation in interventional pain management specifically for diagnostic techniques has not been satisfactorily resolved. There is no consensus with regards to sedation prior to controlled diagnostic blocks and the influence of sedation on the accuracy and validity of the diagnosis. This review is an update to a previous review published in 2009 (29).

\subsection{Studies on Assessing Sedation Analgesia in Interventional Pain Management}

Of the available studies on procedural sedation in interventional pain management, 2 studies (by the same group) described patient preference for IV sedation and anxiety control $(167,168)$. Four studies prospectively evaluated the influence of sedation on post procedure pain ratings: one was an audit of patients treated with epidural steroid injections (169) and 3 studies (by the same group of authors) evaluated changes in pain scores and range of motion after diagnostic medial branch blocks (46-48).

According to one survey, the majority of patients undergoing spinal injection procedures request sedation before the procedure, when given the option. However, in a survey of 500 patients undergoing lumbar, thoracic, and/or cervical spinal injections, only $17 \%$ patients requested sedation before an injection and $\mathbf{2 8 \%}$ indicated that they would request sedation if they were to receive a second injection (167). A second study by the same group did not replicate these results and in fact found that more than half of the patients preferred to receive sedation prior to their spinal injection procedure (168). In this study, 301 consecutive patients were given a choice of oral diazepam, IV diazepam, or no sedation before the spinal injection. One hundred fiftyseven patients $(58 \%)$ chose to have IV sedation. After the injection, patients who chose sedation were asked if they were satisfied with their decision on sedation and if their anxiety about the procedure was effectively controlled with IV sedation. Ninety percent of patients indicated that their anxiety was controlled, while $7 \%$ of patients did not feel that their anxiety was adequately controlled. Furthermore, more patients preferred to be sedated for their second procedure, in contrast to $58 \%$ of patients requesting sedation for the first injection procedure. These findings are similar to those reported by Manchikanti and Giordano (170). It is possible that the differences in the proportion of patients requesting sedation in the 2 studies reflect a wide variance in the number and type of patients requiring sedation for spinal injection procedures. Physicians must therefore consider the physical and psychological characteristics of each patient, and factor these into their decision regarding the use of sedation in their patients.

A prospective audit of pain patients undergoing treatment with epidural steroid injections demonstrated that mild or moderate sedation did not influence post-procedure pain relief, and that there were no significant differences between mean Visual Analog Scale (VAS) or mean differences in VAS scores between those who did or did not receive IV sedation (169).

Manchikanti et al (46-48) evaluated the effect of sedation on pain relief after diagnostic medial branch blocks for cervical facet joints and lumbar facet joints (Table 3 ) in 3 studies that utilized identical methodology and compared pain relief and ability to perform painful movements in patients who received midazolam or fentanyl with a placebo group. There were no significant differences noted either among the groups (IV sodium chloride, midazolam, or fentanyl) or between regions (cervical vs. lumbar). Based on these results, the authors concluded that IV sedation with fentanyl or midazolam does not alter the diagnostic validity of controlled comparative local anesthetic blocks in the cervical or lumbar spine (18). They recommended employing strict outcome criterion such as $\geq 80 \%$ pain relief and an increase in range of previously painful movements. The false-positive rates were $7 \%$ and $8 \%$ (for lumbar and cervical medial branch blocks) when these criterion standards were employed as compared to $13 \%$ and $27 \%$ when these standards were relaxed to $50 \%$ pain relief. Based on limited data, the authors concluded that IV sedation either with midazolam or fentanyl did not adversely affect the diagnostic validity of facet joint nerve blocks in either the cervical spine or lumbar spine, provided strict criterion standards are used. The authors did not include a group that received both midazolam and fentanyl (as is common practice), and therefore it is not known if co-administration of the 2 drugs will lead to similar or different outcomes. 
Table 3. Descriptive characteristics of sedation for interventional techniques.

\begin{tabular}{|c|c|c|c|c|c|}
\hline Study/Methods & Participants & Intervention(s) & Outcome(s) & Result(s) & Conclusion(s) \\
\hline $\begin{array}{l}\text { Manchikanti et al, } \\
2004 \text { (46) } \\
\text { Randomized, } \\
\text { double-blind }\end{array}$ & $\begin{array}{l}180 \text { patients } \\
\text { with cervical } \\
\text { facet joint } \\
\text { pain }\end{array}$ & $\begin{array}{l}\text { Randomization into } \\
3 \text { equal groups (60/ } \\
\text { group); titration of } \\
\text { agent } 1 \mathrm{~mL} \text { at a time; } \\
\text { relaxed or } 5 \mathrm{~mL} \mathrm{max} \\
\text { given. Group I- NaCl } \\
\text { Group II - midazolam } \\
\text { Group III - fentanyl }\end{array}$ & $\begin{array}{l}80 \% \text { pain } \\
\text { relief and abil- } \\
\text { ity to perform } \\
\text { previ- } \\
\text { ously painful } \\
\text { movements }\end{array}$ & $\begin{array}{l}\text { Pain relief of }>80 \% \text { was noted } \\
\text { in } 5 \% \text { of the patients in Group } \\
\text { I, } 8 \% \text { in Group II, and } 8 \% \text { in } \\
\text { Group III. However, }>50 \% \\
\text { relief was noted in } 8 \% \text { of the } \\
\text { patients in Group I, } 13 \% \text { of the } \\
\text { patients in Group II, and } 27 \% \\
\text { of the patients in Group III. } \\
\text { Overall, } 8 \% \text { of the patients in } \\
\text { Group I, } 13 \% \text { in Group II, and } \\
27 \% \text { in Group III were able to } \\
\text { perform movements that were } \\
\text { painful prior to injection. }\end{array}$ & $\begin{array}{l}\text { The administration of } \\
\text { sedation with midazolam or } \\
\text { fentanyl is a confounding fac- } \\
\text { tor in the diagnosis of cervical } \\
\text { facet joint pain in patients } \\
\text { with chronic neck pain. How- } \\
\text { ever, if }>80 \% \text { pain relief with } \\
\text { the ability to perform prior } \\
\text { painful movements is used } \\
\text { as the standard for evaluat- } \\
\text { ing the effect of controlled } \\
\text { local anesthetic blocks, the } \\
\text { diagnostic validity of cervical } \\
\text { facet joint nerve blocks may } \\
\text { be preserved. }\end{array}$ \\
\hline $\begin{array}{l}\text { Manchikanti et al, } \\
2004 \text { (47) } \\
\text { Randomized, } \\
\text { double-blind }\end{array}$ & $\begin{array}{l}180 \text { patients } \\
\text { with lumbar } \\
\text { facet joint } \\
\text { pain }\end{array}$ & $\begin{array}{l}\text { Randomization into } \\
3 \text { equal groups (60/ } \\
\text { group); titration of } \\
\text { agent } 1 \mathrm{~mL} \text { at a time; } \\
\text { relaxed or } 5 \mathrm{~mL} \mathrm{max} \\
\text { given Group I - NaCl } \\
\text { Group II - midazolam } \\
\text { Group III - fentanyl }\end{array}$ & $\begin{array}{l}80 \% \text { pain } \\
\text { relief and abil- } \\
\text { ity to perform } \\
\text { previ- } \\
\text { ously painful } \\
\text { movements }\end{array}$ & $\begin{array}{l}\text { Pain relief of }>80 \% \text { was noted } \\
\text { in } 2 \% \text { of the patients in Group } \\
\text { I, } 5 \% \text { of the patients in Group } \\
\text { II, and } 7 \% \text { in Group III. Pain } \\
\text { relief of }>50 \% \text { was noted in } 7 \% \\
\text { of the patients in Group I, } 5 \% \\
\text { of the patients in Group II, and } \\
13 \% \text { of the patients in Group } \\
\text { III. There were no significant } \\
\text { differences among the groups. }\end{array}$ & $\begin{array}{l}\text { The administration of } \\
\text { sedation with midazolam or } \\
\text { fentanyl is a confounding fac- } \\
\text { tor in the diagnosis of lumbar } \\
\text { facet joint pain in patients } \\
\text { with chronic low back pain. } \\
\text { However, this study suggests } \\
\text { that if strict criteria, including } \\
\text { pain relief and the ability to } \\
\text { perform prior painful move- } \\
\text { ments, are used as the stan- } \\
\text { dard for evaluating the effect } \\
\text { of controlled local anesthetic } \\
\text { blocks, the diagnostic validity } \\
\text { of lumbar facet joint nerve } \\
\text { blocks may be preserved. }\end{array}$ \\
\hline $\begin{array}{l}\text { Manchikanti et al, } \\
2006 \text { (48) } \\
\text { Randomized, } \\
\text { double-blind }\end{array}$ & $\begin{array}{l}60 \text { patients } \\
\text { with com- } \\
\text { bined cervical } \\
\text { facet joint } \\
\text { pain and } \\
\text { lumbar facet } \\
\text { joint pain }\end{array}$ & $\begin{array}{l}\text { Randomization into } \\
3 \text { equal groups ( } 20 \text { / } \\
\text { group); titration of } \\
\text { agent } 1 \mathrm{~mL} \text { at a time; } \\
\text { relaxed or } 5 \mathrm{~mL} \text { max } \\
\text { given } \\
\text { Group I - NaCl } \\
\text { Group II - midazolam } \\
\text { Group III - fentanyl }\end{array}$ & $\begin{array}{l}80 \% \text { pain } \\
\text { relief and abil- } \\
\text { ity to perform } \\
\text { previ- } \\
\text { ously painful } \\
\text { movements }\end{array}$ & $\begin{array}{l}\text { Overall, } 50 \% \text { of the patients } \\
\text { were relaxed or sedated in the } \\
\text { placebo group, while } 100 \% \text { of } \\
\text { the patients in the midazolam } \\
\text { and fentanyl groups were } \\
\text { relaxed or sedated. As many as } \\
10 \% \text { of the patients reported } \\
\text { significant relief ( } 2 \text { reported } \\
80 \% \text { ) with the ability to per- } \\
\text { form prior painful movements. }\end{array}$ & $\begin{array}{l}\text { Perioperative administra- } \\
\text { tion of sodium chloride, } \\
\text { midazolam, or fentanyl can } \\
\text { confound results in the diag- } \\
\text { nosis of combined cervical } \\
\text { and lumbar facet joint pain. } \\
\text { False-positive results with } \\
\text { placebo or sedation may be } \\
\text { seen in a small proportion of } \\
\text { patients. }\end{array}$ \\
\hline
\end{tabular}

Also there is no study that evaluated the influence of IV sedation on other diagnostic injection procedures such as discography and sacroiliac joint blocks.

Discography is a diagnostic interventional procedure performed for the purpose of confirming or refuting a clinical assessment that a specific intervertebral disc is the prominent source of a patient's spinal pain. Provocative discography implies that the procedure provokes a level of discomfort to the pa- tient in order to identify the pain generator. Most studies concerning provocative discography, however, usually do not indicate whether or not sedation analgesia is employed for the procedure. The potential confounding pharmacologic influence imposed by sedation analgesia coupled with the inherent variability and subjectivity in discography techniques and diagnostic criteria can affect the validity of the results (171). 


\subsection{Limitations}

This review is limited by a paucity of studies on this topic in general, and by the absence of data on the influence of sedation, with or without opioids, in diagnosing discogenic pain and sacroiliac joint pain. In addition, 2 groups conducted all of the available studies. One group evaluated overall patient preference for IV sedation prior to spinal injections, while the other group studied the effect of sedation on the diagnostic validity of facet joint nerve blocks in neck and low back pain. The studies by Manchikanti et al (46-48) were placebo-controlled, randomized, double-blind, and evaluated pain relief and pain limited movements. These authors however, did not evaluate the effect of co-administering midazolam and fentanyl, which is the norm for sedation in most interventional pain practices. These studies also did not evaluate the effect of a variable drug dose (midazolam and or fentanyl) on diagnostic validity, i.e., the minimum effective dose to control anxiety and improve patient comfort without significantly altering outcome variables of diagnostic procedures. Future studies should describe the characteristics of patients requiring sedation; compare outcomes in patients receiving oral benzodiazepines or antihistamines (Benadryl) with IV sedation; compare IV sedation to self hypnosis, breathing, or other behavioral diversion strategies; and provide guidelines on optimal drug and dosing combinations.

\subsection{Conclusion}

Most interventional diagnostic spinal procedures are inherently stressful and discomforting to the patient. The ultimate goal is to employ sedation analgesia techniques adapted to the comfort and reassurance level of the patient based upon the expected degree of invasiveness and extent of mental anguish to be evoked by the diagnostic procedure, without impairing the accuracy and validity of the diagnostic test. The essential features that the clinician seeks in a diagnostic test are accuracy, safety, and reproducibility. The general parameters of accuracy are described as the specificity and sensitivity of the diagnostic test. There is no completely reliable "gold standard" with which to compare a diagnostic test or injection in conditions wherein the presence or absence of pain is the end point (172). The potential for compromising the diagnostic criteria for procedural results seems apparent. This narrative review, however, has not found any significant evidence for the influence of sedation with either midazolam or fentanyl in the evaluation of cervical and lumbar facet joint pain with controlled facet joint nerve blocks. There remains a paucity of evidence in the literature to show whether or not other sedation analgesia regimens affect the diagnostic accuracy of various spinal interventional techniques, such as selective nerve root blocks, facet joint injections, sacroiliac joint injections, provocation discography, and spinal cord lead placement trials.

\section{Acknowledgments}

The authors also wish to thank Vidyasagar Pampati, MSc, for statistical assistance; Sekar Edem for assistance in search of literature; Pya Seidner (Department of Anesthesiology, Albany Medical College), Alvaro F. Gómez, MA, and Laurie Swick, BS, for manuscript review and Tonie M. Hatton and Diane E. Neihoff, transcriptionists (Pain Management Center of Paducah), for their assistance in preparation of this manuscript. The authors thank Pain Physician for permission to reproduce Smith et al's manuscript from 2009 (29). We would like to thank the editorial board of Pain Physician for review and criticism in improving the manuscript.

\section{References}

1. Krauss B, Green SM. Procedural sedation and analgesia in children. Lancet 2006; 367:766-780.

2. Krauss B, Green SM. Sedation and analgesia for procedures in children. N Engl] Med 2000; 342:938-945.

3. Bhatt $M$, Kennedy RM, Osmond $\mathrm{MH}$, Krauss B, McAllister JD, Ansermino JM, Evered LM, Roback MG; Consensus Panel on Sedation Research of Pediatric Emergency Research Canada (PERC) and the Pediatric Emergency Care Applied Research Network (PECARN). Consensus-based recommendations for stan- dardizing terminology and reporting adverse events for emergency department procedural sedation and analgesia in children. Ann Emerg Med 2009; 53:426435 .

4. Mason KP, Green SM, Piacevoli Q; International Sedation Task Force. Adverse event reporting tool to standardize the reporting and tracking of adverse events during procedural sedation: A consensus document from the World SIVA International Sedation Task Force. Br J Anaesth 2012; 108:13-20.

5. Jones DR, Salgo P, Meltzer J. Videos in clinical medicine. Conscious sedation for minor procedures in adults. $N$ Engl J Med 2011; 364:e54.

6. Colson JD. The pharmacology of sedation. Pain Physician 2005; 8:297-308.

7. Colson JD, Boswell MV. Procedural sedation analgesia. In: Manchikantil, Singh V (eds). Interventional Techniques in Chronic Spinal Pain. ASIPP Publishing, Paducah, KY, 2007, pp 197-206.

8. Patki A, Shelgaonkar VC. A comparison of equisedative infusions of propofol and midazolam for conscious sedation during spinal anesthesia: A prospective 
randomized study. J Anaesthesiol Clin Pharmacol 2011; 27:47-53.

9. Bhananker SM, Posner KL, Cheney FW, Caplan RA, Lee LA, Domino KB. Injury and liability associated with monitored anesthesia care: A closed claims analysis. Anesthesiology 2006; 104:228-234.

10. Institute of Medicine. To Err is Human: Building A Safer Health System. The National Academies Press, Washington, DC, November 1, 1999.

http://iom.edu/Reports/1999/To-Err-isHuman-Building-A-Safer-Health-System.aspx

11. World Health Organization, The Uppsala Monitoring Centre. www.who-umc. org

12. European Medicines Agency. ICH Topic E 2 A. Clinical Safety Data Management: Definitions and Standards for Expedited Reporting. Approval by CPMP: November 1994. Date for coming into operation: June 1995. http://www.ema. europa.eu/docs/en_GB/document_library/Scientific_guideline/2009/09/ WC500002749.pdf

13. European Medicines Agency. ICH Topic E $6(\mathrm{RI})$. Guideline for Good Clinical Practice. Note for Guidance on Good Clinical Practice. Final approval by CPMP: July 1996. Date for coming into operation: January 1997. Post step errata (linguistic minor corrections): July 2002. http://www.ema.europa.eu/docs/en_ GB/document_library/Scientific_guideline/2009/09/WC50000 2874.pdf

14. United States Food and Drug Administration. Adverse event definitions. http://www.fda.gov/safety/medwatch/ howtoreport/ucm053087.htm

15. Ahmed SU, Tonidandel W, Trella J, Martin NM, Chang Y. Peri-procedural protocols for interventional pain management techniques: A survey of US pain centers. Pain Physician 2005; 8:181-185.

16. Kamata K, Komatsu R, Ozaki M, Hagihira S. Predominant effects of midazolam for conscious sedation: Benefits beyond the early postoperative period. J Anesth 2010; 24:869-876.

17. Rathmell JP, Michna E, Fitzgibbon DR, Stephens LS, Posner KL, Domino KB. Injury and liability associated with cervical procedures for chronic pain. Anesthesiology 2011; 114:918-926.

18. Manchikanti L, Boswell MV, Manchukonda R, Cash KA, Giordano J. Influence of prior opioid exposure on diagnostic facet joint nerve blocks. J Opioid Manage 2008; 4:351-36o.
19. Manchikanti L, Pampati V, Fellows B, Rivera JJ, Damron KS, Beyer CD, Cash KA. Influence of psychological factors on the ability to diagnose chronic low back pain of facet joint origin. Pain Physician 2001; 4:349-357.

20. Manabat ER, Pujol LA, Hunt P, Wang D. Judging pain sensitivity with subcutaneous lidocaine injections. Pain Medicine 2011; 12:668-672.

21. Dersh J, Mayer T, Theodore BR, Polatin P, Gatchel RJ. Do psychiatric disorders first appear preinjury or postinjury in chronic disabling occupational spinal disorders? Spine (Phila Pa 1976) 2007; 32:1045-1051.

22. Rush AJ, Polatin P, Gatchel RJ. Depression and chronic low back pain. Spine (Phila Pa 1976) 2000; 25:2566-2571.

23. Manchikanti L, Pampati V, Fellows B, Beyer CD, Damron KS, Barnhill RC, Burks TA. Characteristics of chronic low back pain in patients in an interventional pain management setting: A prospective evaluation. Pain Physician 2001; 4:131-142.

24. Manchikanti L, Singh V, Pampati VS, Fellows B, Beyer C, Damron K, Cash KA. Provocative discography in low back pain patients with or without somatization disorder: A randomized prospective evaluation. Pain Physician 2001; 4:227239.

25. Manchikanti L, Abdi S, Atluri S, Balog CC, Benyamin RM, Boswell MV, Brown KR, Bruel BM, Bryce DA, Burks PA, Burton AW, Calodney AK, Caraway DL, Cash KA, Christo PJ, Damron KS, Datta S, Deer TR, Diwan S, Eriator I, Falco FJE, Fellows F, Geffert S, Gharibo CG, Glaser SE, Grider JS, Hameed H, Hameed M, Hansen H, Harned ME, Hayek SM, Helm II S, Hirsch JA, Janata JW, Kaye AD, Kaye AM, Kloth DS, Koyyalagunta D, Lee M, Malla Y, Manchikanti KN, McManus CD, Pampati V, Parr AT, Pasupuleti R, Patel VB, Sehgal N, Silverman SM, Singh V, Smith HS, Snook LT, Solanki DR, Tracy DH, Vallejo R, Wargo BW. American Society of Interventional Pain Physicians (ASIPP) guidelines for responsible opioid prescribing in chronic non-cancer pain: Part I - Evidence assessment. Pain Physician 2012; 15:S1-S66.

26. Manchikanti L, Abdi S, Atluri S, Balog CC, Benyamin RM, Boswell MV, Brown KR, Bruel BM, Bryce DA, Burks PA, Burton AW, Calodney AK, Caraway DL, Cash KA, Christo PJ, Damron KS, Datta S, Deer TR, Diwan S, Eriator I, Falco FJE, Fellows F, Geffert S, Gharibo CG, Glaser SE, Grider JS, Hameed H, Hameed
M, Hansen $\mathrm{H}$, Harned ME, Hayek SM, Helm II S, Hirsch JA, Janata JW, Kaye AD, Kaye AM, Kloth DS, Koyyalagunta D, Lee M, Malla Y, Manchikanti KN, McManus CD, Pampati V, Parr AT, Pasupuleti R, Patel VB, Sehgal N, Silverman SM, Singh V, Smith HS, Snook LT, Solanki DR, Tracy DH, Vallejo R, Wargo BW. American Society of Interventional Pain Physicians (ASIPP) guidelines for responsible opioid prescribing in chronic non-cancer pain: Part 2-Guidance. Pain Physician 2012; 15:S67-S116.

27. Manchikanti L, Helm II S, Fellows B, Janata JW, Pampati V, Grider JS, Boswell MV. Opioid epidemic in the United States. Pain Physician 2012; 15:ES9-ES38.

28. Manchikanti L, Boswell MV, Singh V, Benyamin RM, Fellows B, Abdi S, Buenaventura RM, Conn A, Datta S, Derby R, Falco FJE, Erhart S, Diwan S, Hayek SM, Helm S, Parr AT, Schultz DM, Smith HS, Wolfer LR, Hirsch JA. Comprehensive evidence-based guidelines for interventional techniques in the management of chronic spinal pain. Pain Physician 2009; 12:699-802.

29. Smith HS, Chopra P, Patel VB, Frey ME, Rastogi R. Systematic review on the role of sedation in diagnostic spinal interventional techniques. Pain Physician 2009; 12:195-206.

30. Singh V, Manchikanti L, Onyewu O, Benyamin RM, Datta S, Geffert S, Parr AT, Falco FJE. An update of appraisal of accuracy of thoracic discography as a diagnostic test for chronic spinal pain. Pain Physician 2012; 15:E757-E776.

31. Onyewu O, Manchikanti L, Falco FJE, Singh V, Geffert S, Helm II S, Cohen SP, Hirsch JA. An update of the appraisal of the accuracy and utility of cervical discography in chronic neck pain. Pain Physician 2012; 15:E777-E806.

32. Falco FJE, Manchikanti L, Datta S, Sehgal N, Geffert S, Onyewu O, Singh V, Bryce DA, Benyamin RM, Simopoulos TT, Vallejo R, Gupta S, Ward SP, Hirsch JA. An update of the systematic assessment of the diagnostic accuracy of lumbar facet joint nerve blocks. Pain Physician 2012; 15:E869-E907.

33. Falco FJE, Datta S, Manchikanti L, Sehgal N, Geffert S, Singh V, Smith HS, Boswell MV. An updated review of diagnostic utility of cervical facet joint injections. Pain Physician 2012; 15:E807-E838.

34. Atluri $S$, Singh $V$, Datta $S$, Geffert $S$, Sehgal N, Falco FJE. Diagnostic accuracy of thoracic facet joint nerve blocks: An update of the assessment of evidence. Pain 
Physician 2012; 15:E483-E496.

35. Simopoulos TT, Manchikanti L, Singh V, Gupta S, Hameed H, Diwan S, Cohen SP. A systematic evaluation of prevalence and diagnostic accuracy of sacroiliac joint interventions. Pain Physician 2012; 15:E305-E344.

36. Manchikanti L, Benyamin RM, Singh V, Falco FJE, Hameed H, Derby R, Wolfer LR, Helm II S, Calodney AK, Datta S, Snook LT, Caraway DL, Hirsch JA, Cohen SP. An update of the systematic appraisal of the accuracy of utility of lumbar discography in chronic low back pain. Pain Physician 2013;

37. Carragee EJ, Haldeman S, Hurwtiz E. The pyrite standard: The Midas touch in the diagnosis of axial pain syndromes. Spine J 2007; 7:27-31.

38. Carragee EJ. Is lumbar discography a determinate of discogenic low back pain: Provocative discography reconsidered. Curr Rev Pain 2000; 4:301-308.

39. Carragee EJ, Chen Y, Tanner CM, Truong T, Lau E, Brito JL. Provocative discography in patients after limited lumbar discectomy: A controlled, randomized study of pain response in symptomatic and asymptomatic subjects. Spine (Phila $\mathrm{Pa} \mathrm{1976)} \mathrm{2000;} \mathrm{25:3065-3071.}$

40. Carragee EJ, Tanner CM, Khurana S, Hayward C, Welsh J, Date E, Truong T, Rossi M, Hagle C. The rates of false positive lumbar discography in select patients without low back symptoms. Spine (Phila Pa 1976) 2000; 25:1373-1381.

41. Cohen SP, Raja SN. Pathogenesis, diagnosis and treatment of lumbar zygapophysial (facet) joint pain. Anesthesiology 2007; 106:591-614.

42. Hogan QH, Abram SE. Neural blockade for diagnosis and prognosis: A review. Anesthesiology 1997; 86:216-241.

43. Cohen SP, Larkin T, Chang A, Stojanovic MP. The causes of false-positive medial branch blocks in soldiers and retirees. Mil Med 2004; 169:781-786.

44. Cohen SP, Mullings R, Abdi S. The pharmacologic treatment of muscle pain. Anesthesiology 2004; 101:495-526.

45. Frölich MA, Zhang K, Ness TJ. Effect of sedation on pain perception. Anesthesiology 2013 Jan 11. [Epub ahead of print]

46. Manchikanti L, Damron KS, Rivera J, McManus CD, Jackson SD, Barnhill RC, Martin JC. Evaluation of effect of sedation as a confounding factor in the diagnostic validity of lumbar facet joint pain: A prospective, randomized, double-blind, placebo-controlled evalua- tion. Pain Physician 2004; 7:411-417.

47. Manchikanti L, Pampati V, Damron KS, McManus CD, Jackson SD, Barnhill RC, Martin JC. A randomized, prospective, double-blind, placebo-controlled evaluation of the effect of sedation on diagnostic validity of cervical facet joint pain. Pain Physician 2004; 7:301-309.

48. Manchikanti L, Pampati V, Damron KS, McManus CD, Jackson SD, Barnhill RC, Martin JC. The effect of sedation on diagnostic validity of facet joint nerve blocks: An evaluation to assess similarities in population with involvement in cervical and lumbar regions. Pain Physician 2006; 9:47-52.

49. Manchikanti L, Pampati V, Damron KS. The role of placebo and nocebo effects of perioperative administration of sedatives and opioids in interventional pain management. Pain Physician 2005; 8:349-355.

50. Pampati S, Cash KA, Manchikanti L. Accuracy of diagnostic lumbar facet joint nerve blocks: A 2-year follow-up of 152 patients diagnosed with controlled diagnostic blocks. Pain Physician 2009; 12:855-866.

51. Manchikanti L, Pampati S, Cash KA. Making sense of the accuracy of diagnostic lumbar facet joint nerve blocks: An assessment of implications of 50\% relief, $80 \%$ relief, single block or controlled diagnostic blocks. Pain Physician 2010; 13:133-143.

52. Lord SM, Barnsley L, Bogduk N. The utility of comparative local anesthetic blocks versus placebo-controlled blocks for the diagnosis of cervical zygapophysial joint pain. Clin J Pain 1995; 11:208213.

53. Barnsley L, Bogduk N. Medial branch blocks are specific for the diagnosis of cervical zygapophyseal joint pain. Reg Anesth 1993; 18:343-350.

54. Hansen H, Manchikanti L, Simopoulous TT, Christo PJ, Gupta S, Smith HS, Hameed $\mathrm{H}$, Cohen SP. A systematic evaluation of the therapeutic effectiveness of sacroiliac joint interventions. Pain Physician 2012; 15:E247-E278.

55. Helm S II, Deer TR, Manchikanti L, Datta S, Chopra P, Singh V, Hirsch JA. Effectiveness of thermal annular procedures in treating discogenic low back pain. Pain Physician 2012; 15:E279-E304.

56. Manchikanti KN, Atluri S, Singh V, Geffert S, Sehgal N, Falco FJE. An update of evaluation of therapeutic thoracic facet joint interventions. Pain Physician 2012; 15: $\mathrm{E}_{463}-\mathrm{E}_{4} 81$.
57. Falco FJE, Manchikanti L, Datta S, Wargo BW, Geffert S, Bryce DA, Atluri S, Singh V, Benyamin RM, Sehgal N, Ward S, Helm II S, Gupta S, Boswell MV. Systematic review of therapeutic effectiveness of cervical facet joint interventions: An update. Pain Physician 2012; 15:E839E868.

58. Falco FJE, Manchikanti L, Datta S, Sehgal N, Geffert S, Onyewu O, Zhu J, Coubarous $S$, Hameed M, Ward SP, Sharma $M$, Hameed H, Singh V, Boswell MV. An update of the effectiveness of therapeutic lumbar facet joint interventions. Pain Physician 2012; 15:E909-E953.

59. Davis PJ, Reeves JL, Hastie BA, GraffRadford SB, Naliboff BD. Depression determines illness conviction and pain impact: A structural equation modeling analysis. Pain Med 2000; 1:238-246.

6o. Aronoff GM, Tota-Faucette M, Phillips L, Lawrence $\mathrm{CN}$. Are pain disorder and somatization disorder valid diagnostic entities. Curr Rev Pain 2000; 4:309-312.

61. Bacon NM, Bacon SF, Atkinson JH, Slater MA, Patterson TL, Grant I, Garfin SR. Somatization symptoms in chronic low back pain patients. Psychosom Med 1994; 56:118-127.

62. Fishbain DA. Somatization, secondary gain, and chronic pain: Is there a relationship? Curr Rev Pain 1998; 6:101-108.

63. Korbon GA, DeGood DE, Schroeder ME, Slater MA, Patterson TL, Grant I, Garfin SR. The development of a somatic amplication rating scale for low back pain. Spine (Phila Pa 1976) 1987; 12:787-791.

64. Sikorski JM, Stampfer HG, Cole RM, Wheatley AE. Psychological aspects of chronic low back pain. Aust N Z J Surg 1966; 66:294-297.

65. Tollison CD, Satterthwaite JR. Chronic benign pain: Diagnosis and behavioral management. J Musculoskeletal Med 1991; 8:55-66.

66. Bair MJ, Robinson RL, Katon W, Kroenke K. Depression and pain comorbidity: A literature review. Arch Intern Med 2003; 163:2433-2445.

67. Epker J, Block AR. Presurgical psychological screening in back pain patients: A review. Clin J Pain 2001; 17:200-205.

68. Burns J, Johnson B, Mahoney N, Devine J, Pawl R. Cognitive and physical capacity process variables predict long term outcome after treatment of chronic pain. J Clin Consult Psychiatry 1998; 66:434-439.

69. Carette S, Marcoux S, Truchon R, Grondin C, Gagnon J, Allard Y, Latulippe M. A controlled trial of corticosteroid in- 
jections into facet joints for chronic low back pain. N Engl J Med 1991; 325:10021007.

70. Carette S, Leclaire R, Marcoux S, Morin F, Blaise GA, St-Pierre A, Truchon R, Parent F, Levesque J, Bergeron V, Montminy $P$, Blanchette $C$. Epidural corticosteroid injections for sciatica due to herniated nucleus pulposus. $N$ Engl J Med 1997; 336:1634-1640.

71. Karppinen J, Malmivaara A, Kurunlahti $M$, Kyllönen E, Pienimäki T, Nieminen P, Ohinmaa A, Tervonen O, Vanharanta $H$. Periradicular infiltration for sciatica: A randomized controlled trial. Spine (Phila Pa 1976) 2001; 26:1059-1067.

72. Louhiala P, Puustinen R. Rethinking the placebo effect.] Med Ethics 2008; 34:107109.

73. Louhiala P. The ethics of the placebo in clinical practice revisited. J Med Ethics 2009; 35:407-409.

74. Blease C. The principle of parity: The "placebo effect" and physician communication. J Med Ethics 2012; 38:199-203.

75. Lyby PS, Forsberg JT, Asli O, Flaten MA. Induced fear reduces the effectiveness of a placebo intervention on pain. Pain 2012; 153:1114-1121.

76. Häuser W, Bartram C, Bartram-Wunn $\mathrm{E}$, Tölle T. Adverse events attributable to nocebo in randomized controlled drug trials in fibromyalgia syndrome and painful diabetic peripheral neuropathy: Systematic review. Clin J Pain 2012; 28:437-451.

77. Manchikanti L, Giordano J, Fellows B, Hirsch JA. Placebo and nocebo in interventional pain management: $A$ friend or a foe - or simply foes? Pain Physician 2011; 14:E157-E175.

78. Data-Franco J, Berk M. The nocebo effect: A clinicians guide. Aust N Z J Psychiatry 2012 Oct 23. [Epub ahead of print].

79. Jensen KB, Kaptchuk TJ, Kirsch I, Raicek J, Lindstrom KM, Berna C, Gollub RL, Ingvar $\mathrm{M}$, Kong J. Nonconscious activation of placebo and nocebo pain responses. Proc Natl Acad Sci U S A 2012; 109:15959-15964.

8o. Kvolik S, Juki M, Fingler M. Placebo in the pain treatment. Lijec Vjesn 2012; 134:233-241.

81. Bingel U, Tracey I, Wiech K. Neuroimaging as a tool to investigate how cognitive factors influence analgesic drug outcomes. Neurosci Lett 2012; 520:149155 .

82. Atlas LY, Wager TD. How expectations shape pain. Neurosci Lett 2012; 520:140148.

83. Benedetti F. Placebo-induced improvements: How therapeutic rituals affect the patient's brain. J Acupunct Meridian Stud 2012; 5:97-103.

84. Meynen G, Swaab DF. Why medication in involuntary treatment may be less effective: The placebo/nocebo effect. Med Hypotheses 2011; 77:993-995.

85. Lemoine P. The placebo mystery or neurobiology of the soul. Bull Acad Natl Med 2011; 195:1465-1476.

86. Carlino E, Pollo A, Benedetti F. Placebo analgesia and beyond: A melting pot of concepts and ideas for neuroscience. Curr Opin Anaesthesiol 2011; 24:540-544.

87. Kradin R. The placebo response: An attachment strategy that counteracts the effects of stress-related dysfunction. Perspect Biol Med 2011; 54:438-454.

88. Dobrila-Dintinjana R, NacinoviםDuleti A. Placebo in the treatment of pain. Coll Antropol 2011; 35:319-323.

89. Benedetti F, Amanzio M. The placebo response: How words and rituals change the patient's brain. Patient Educ Couns 2011; 84:413-419.

90. Colloca L, Miller FG. Harnessing the placebo effect: The need for translational research. Philos Trans R Soc Lond B Bio Sci 2011; 366:1922-1930.

91. Colloca L, Miller FG. How placebo responses are formed: A learning perspective. Philos Trans $R$ Soc Lond B Biol Sci 2011; 366:1859-1869.

92. Flaten MA, Aslaksen PM, Lyby PS, Bjørkedal E. The relation of emotions to placebo responses. Philos Trans R Soc Lond B Biol Sci 2011; 366:1818-1827.

93. Meissner K. The placebo effect and the autonomic nervous system: Evidence for an intimate relationship. Philos Trans R Soc Lond B Biol Sci 2011; 366:1808-1817.

94. Pollo A, Carlino E, Benedetti F. Placebo mechanisms across different conditions: From the clinical setting to physical performance. Philos Trans R Soc Lond B Biol Sci 2011; 366:1790-1798.

95. Meissner K, Kohls N, Colloca L. Introduction to placebo effects in medicine: Mechanisms and clinical implications. Philos Trans R Soc Lond B Biol Sci 2011; 366:1783-1789.

96. Weeks RE, Newman E. Behavioral factors in the placebo response. Neurol $\mathrm{Sc}$ 2011; 32:S3-S8.

97. Berthelot JM. The placebo effect in rheumatology: New data. Joint Bone Spine 2011; 78:161-165.
98. Lee $\mathrm{M}$, Silverman $\mathrm{SM}$, Hansen $\mathrm{H}$, Patel VB, Manchikanti L. A comprehensive review of opioid-induced hyperalgesia. Pain Physician 2011; 14:145-161.

99. Kradin RL. Placebo response: A consideration of its role in therapeutics. Curr Psychiatry Rep 2011; 13:37-42.

100. Bingel U, Colloca L, Vase L. Mechanisms and clinical implications of the placebo effect: Is there a potential for the elderly? A mini-review. Gerontology 2011; 57:354-363.

101. Tracey I. Getting the pain you expect: Mechanisms of placebo, nocebo and reappraisal effects in humans. Nat Med 2010; 16:1277-1283.

102. Chua NH, Vissers KC, Arendt-Nielsen L, Wilder-Smith $\mathrm{OH}$. Do diagnostic blocks have beneficial effects on pain processing? Reg Anesth Pain Med 2011; 36:317321.

103. Häuser W, Hansen E, Enck P. Nocebo phenomena in medicine: Their relevance in everyday clinical practice. Dtsch Arztebl Int 2012; 109:459-465.

104. Colloca L, Miller FG. The nocebo effect and its relevance for clinical practice. Psychosom Med 2011; 73:598-603.

105. van Laarhoven Al, Vogelaar ML, WilderSmith OH, van Riel PL, van de Kerkhof PC, Kraaimaat FW, Evers AW. Induction of nocebo and placebo effects on itch and pain by verbal suggestions. Pain 2011; 152:1486-1494.

106. Crombez G, Wiech K. You may (not always) experience what you expect: In search for the limits of the placebo and nocebo effect. Pain 2011; 152:1449-1450.

107. Weissenfeld J, Stock S, Lüngen M, Gerber A. The nocebo effect: A reason for patients' non-adherence to generic substitution? Pharmazie 2010; 65:451-456.

108. Quill TE, Holloway RG. Evidence, preferences, recommendations--finding the right balance in patient care. $N$ Engl J Med 2012; 366:1653-1655.

109. Gelijns AC, Gabriel SE. Looking beyond translation--integrating clinical research with medical practice. $N$ Engl J Med 2012; 366:1659-1661.

110. Oxman AD, Guyatt GH. Guidelines for reading literature reviews. CMA] 1988; 138:697-703.

111. Bisby MA. Inhibition of axonal transport in nerves chronically treated with local anesthetics. Exp Neurol 1975; 47:481-489.

112. Howick J, Bishop FL, Heneghan, Wolstenholme J, Stevens S, Hobbs FDR, Lewith G. Placebo use in the United Kingdom: Results from a national sur- 
vey of primary care practitioners. PLOS One 2013; in publication.

113. Livingston EH, McNutt RA. The hazards of evidence-based medicine: Assessing variations in care. JAMA 2011; 306:762763.

114. Hróbjartsson A, Kaptchuk TJ, Miller FG. Placebo effect studies are susceptible to response bias and to other types of biases. J Clin Epidemiol 2011; 64:1223-1229.

115. Hróbjartsson A. What are the main methodological problems in the estimation of placebo effects. J Clin Epidemiol 2002; 55:430-435.

116. Beecher HK. The powerful placebo. J Am Med Assoc 1955; 159:1602-1606.

117. Kienle GS, Kiene $H$. The powerful placebo effect: Fact or fiction?] Clin Epidemiol 1997; 50:1311-1318.

118. Hróbjartson A, Gotzsche PC. Is the placebo powerless? An analysis of clinical trials comparing placebo with no treatment. N Eng J Med 2001; 344:1594-1602.

119. Grigoras A, Lee P, Sattar F, Shorten G. Perioperative intravenous lidocaine decreases the incidence of persistent pain after breast surgery. Clin J Pain 2012; 28:567-572.

120. Cui W, Li Y, Li S, Wang R, Li J. Systemic administration of lidocaine reduces morphine requirements and postoperative pain of patients undergoing thoracic surgery after propofol-remifentanil based anaesthesia. Eur J Anaesthesiol 2010; 27:41-46.

121. Koppert W, Zeck S, Sittl R. Low dose lidocaine suppresses experimentally induced hyperalgesia in humans. Anesthesiology 1998; 89:1345-1353.

122. Koppert W, Ostermaier N, Sittl R, Weidner C, Schmelz M. Low dose lidocaine reduces secondary hyperalgesia by a central mode of action. Pain 2000; 85:217-224.

123. Kawamata M, Takahashi T, Kozuka $Y$, Nawa Y, Nishikawa K, Narimatsu E, Watanabe $\mathrm{H}$, Namiki A. Experimental incision induced pain in human skin: Effects of systemic lidocaine on flare formation and hyperalgesia. Pain 2002; 100:77-89.

124. Hollmann MW, Durieux M. Local anesthetics and the inflammatory response. Anesthesiology 2000; 93:858-875.

125. Sugimoto $M$, Uchida I, Mashimoto T. Local anaesthetics have different mechanisms and sites of action at the recombinant NMDA receptors. $\mathrm{Br}$ J Pharmacol 2003; 138:876-882.

126. Sen $H$, Kulahci $Y$, Bicerer E, Ozkan $S$,
Dagli G, Turan A. The analgesic effect of paracetamol when added to lidocaine for intravenous regional anesthesia. Anesth Analg 2009; 109:1327-1330.

127. Baral BK, Bhattarai BK, Rahman TR, Singh SN, Regmi R. Perioperative intravenous lidocaine infusion on postoperative pain relief in patients undergoing upper abdominal surgery. Nepal Med Coll ] 2010; 12:215-220.

128. Koppert W, Weigand M, Neumann F, Sittl R, Schuettler J, Schmelz M, Hering $W$. Perioperative intravenous lidocaine has preventive effects on postoperative pain and morphine consumption after major abdominal surgery. Anesth Analg 2004; 98:1050-1055.

129. Martin F, Cherif K, Gentili ME, Enel D, Abe E, Alvarez JC, Mazoit JX, Chauvin M, Bouhassira D, Fletcher D. Lack of impact of intravenous lidocaine on analgesia, functional recovery, and nociceptive pain threshold after total hip arthroplasty. Anesthesiology 2008; 109:118-123.

130. Lavand'homme P, De Kock M, Waterloos $\mathrm{H}$. Intraoperative epidural analgesia combined with ketamine provides effective preventive analgesia in patients undergoing major digestive surgery. Anesthesiology 2005; 103:813-820.

131. McCarthy GC, Megalla SA, Habib AS. Impact of intravenous lidocaine infusion on postoperative analgesia and recovery from surgery: A systematic review of randomized controlled trials. Drugs 2010; 70:1149-1163.

132. Jankovic RJ, Visnjic MM, Milic DJ, Stojanovic MP, Djordjevic DR, Pavlovic MS. Does the addition of ketorolac and dexamethasone to lidocaine intravenous regional anesthesia improve postoperative analgesia and tourniquet tolerance for ambulatory hand surgery? Minerva Anestesiol 2008; 74:521-527.

133. Fujii Y, Itakura M. Comparison of lidocaine, metoclopramide, and flurbiprofen axetil for reducing pain on injection of propofol in Japanese adult surgical patients: A prospective, randomized, double-blind, parallel-group, placebocontrolled study. Clin Ther 2008; 30:280286.

134. Kwak KH, Ha J, Kim Y, Jeon Y. Efficacy of combination intravenous lidocaine and dexamethasone on propofol injection pain: A randomized, double-blind, prospective study in adult Korean surgical patients. Clin Ther 2008; 30:1113-1119.

135. Parr AT, Manchikanti L, Hameed $\mathrm{H}$, Conn A, Manchikanti KN, Benyamin RM, Diwan S, Singh V, Abdi S. Caudal epidural injections in the management of chronic low back pain: A systematic appraisal of the literature. Pain Physician 2012; 15:E159-E198.

136. Benyamin RM, Manchikanti L, Parr AT, Diwan SA, Singh V, Falco FJE, Datta S, Abdi S, Hirsch JA. The effectiveness of lumbar interlaminar epidural injections in managing chronic low back and lower extremity pain. Pain Physician 2012; 15:E363-E404.

137. Diwan SA, Manchikanti L, Benyamin RM, Bryce DA, Geffert S, Hameed H, Sharma ML, Abdi S, Falco FJE. Effectiveness of cervical epidural injections in the management of chronic neck and upper extremity pain. Pain Physician 2012; 15:E405-E434.

138. Benyamin RM, Wang VC, Vallejo R, Singh V, Helm S II. A systematic evaluation of thoracic interlaminar epidural injections. Pain Physician 2012; 15:E497E514.

139. Manchikanti L, Buenaventura RM, Manchikanti KN, Ruan X, Gupta S, Smith HS, Christo PJ, Ward SP. Effectiveness of therapeutic lumbar transforaminal epidural steroid injections in managing lumbar spinal pain. Pain Physician 2012; 15:E199-E245.

140. Manchikanti L, Cash KA, McManus CD, Pampati V, Smith HS. One year results of a randomized, double-blind, active controlled trial of fluoroscopic caudal epidural injections with or without steroids in managing chronic discogenic low back pain without disc herniation or radiculitis. Pain Physician 2011; 14:25-36.

141. Manchikanti L, Cash KA, McManus CD, Pampati V. Fluoroscopic caudal epidural injections in managing chronic axial low back pain without disc herniation, radiculitis or facet joint pain. J Pain Res 2012; 5:381-390.

142. Manchikanti L, Singh V, Cash KA, Pampati V, Damron KS, Boswell MV. A randomized, controlled, double-blind trial of fluoroscopic caudal epidural injections in the treatment of lumbar disc herniation and radiculitis. Spine (Phila Pa 1976) 2011; 36:1897-1905.

143. Manchikanti L, Singh V, Cash KA, Pampati V, Damron KS, Boswell MV. Effect of fluoroscopically guided caudal epidural steroid or local anesthetic injections in the treatment of lumbar disc herniation and radiculitis: A randomized, controlled, double blind trial with a two-year follow-up. Pain Physician 2012; 15:273-286.

144. Manchikanti L, Singh V, Cash KA, Pam- 
pati V, Datta S. Fluoroscopic caudal epidural injections in managing post lumbar surgery syndrome: Two-year results of a randomized, double-blind, activecontrol trial. Int J Med Sci 2012; 9:582591.

145. Manchikanti L, Cash KA, McManus CD, Pampati V, Fellows B. Fluoroscopic caudal epidural injections with or without steroids in managing pain of lumbar spinal stenosis: One year results of randomized, double-blind, active-controlled trial. J Spinal Disord Tech 2012; 25:226-234.

146. Manchikanti L, Cash KA, McManus CD, Pampati V, Fellows B. Results of 2-year follow-up of a randomized, doubleblind, controlled trial of fluoroscopic caudal epidural injections in central spinal stenosis. Pain Physician 2012; 15:371384 .

147. Manchikanti L, Singh V, Cash KA, Pampati $\vee$, Falco FJE. The role of fluoroscopic interlaminar epidural injections in managing chronic pain of lumbar disc herniation or radiculitis: A randomized, double-blind trial. Pain Pract 2012 Dec. 27. [Epub ahead of print].

148. Manchikanti L, Cash KA, McManus CD, Pampati V, Benyamin R. Fluoroscopic lumbar interlaminar epidural injections in managing chronic lumbar axial or discogenic pain. J Pain Res 2012; 5:301311.

149. Manchikanti L, Cash KA, McManus CD, Damron KS, Pampati V, Falco FJE. Lumbar interlaminar epidural injections in central spinal stenosis: Preliminary results of a randomized, double-blind, active control trial. Pain Physician 2012; 15:51-63.

150. Manchikanti L, Cash KA, Pampati V, Malla Y. Fluoroscopic cervical epidural injections in chronic axial or disc-related neck pain without disc herniation, facet joint pain, or radiculitis. J Pain Res 2012; 5:227-236.

151. Manchikanti L, Cash KA, Pampati V, Wargo BW, Malla Y. Management of chronic pain of cervical disc herniation and radiculitis with fluoroscopic cervical interlaminar epidural injections. Int
] Med Sci 2012; 9:424-434.

152. Manchikanti L, Malla Y, Cash KA, McManus $C D$, Pampati $V$. Fluoroscopic epidural injections in cervical spinal stenosis: Preliminary results of a randomized, double-blind, active control trial. Pain Physician 2012; 15:E59-E70.

153. Manchikanti L, Malla Y, Cash KA, McManus CD, Pampati V. Fluoroscopic cervical interlaminar epidural injections in managing chronic pain of cervical postsurgery syndrome: Preliminary results of a randomized, double-blind active control trial. Pain Physician 2012; 15:1326.

154. Sato C, Sakai A, Ikeda Y, Suzuki H, Sakamoto A. The prolonged analgesic effect of epidural ropivacaine in a rat model of neuropathic pain. Anesth Analg 2008; 106:313-320.

155. Tachihara H, Sekiguchi M, Kikuchi S, Konno S. Do corticosteroids produce additional benefit in nerve root infiltration for lumbar disc herniation. Spine (Phila Pa 1976) 2008; 33:743-747.

156. Mao J, Chen LL. Systemic lidocaine for neuropathic pain relief. Pain 2000; 87:717.

157. Pasqualucci A. Experimental and clinical studies about the preemptive analgesia with local anesthetics. Possible reasons of the failure. Minerva Anestesiol 1998; 64:445-457.

158. Arner S, Lindblom U, Meyerson BA, Molander $\mathrm{C}$. Prolonged relief of neuralgia after regional anesthetic block. A call for further experimental and systematic clinical studies. Pain 1990; 43:287-297.

159. Lavoie PA, Khazen T, Filion PR. Mechanisms of the inhibition of fast axonal transport by local anesthetics. Neuropharmacology 1989; 28:175-181.

160. Cassuto J, Sinclair R, Bonderovic M. Anti-inflammatory properties of local anesthetics and their present and potential clinical implications. Acta Anaesthesiol Scand 2006; 50:265-282.

161. Melzack R, Coderre TJ, Katz J, Vaccarino AL. Central neuroplasticity and pathological pain. Ann N Y Acad Sci 2001; 933:157-174.
162. Hildebrandt J. Relevance of nerve blocks in treating and diagnosing low back pain--is the quality decisive? Schmerz 2001; 15:474-483.

163. Han KR, Kim C, Chae YJ, Kim DW. Efficacy and safety of high concentration lidocaine for trigeminal nerve block in patients with trigeminal neuralgia. Int ] Clin Pract 2008; 62:248-254.

164. Araujo MC, Sinnott CJ, Strichartz GR. Multiple phases of relief from experimental mechanical allodynia by systemic lidocaine: Responses to early and late infusions. Pain 2003; 103:21-29.

165. Wolff AP, Wilder Smith OH, Crul BJ, van de Heijden MP, Groen GJ. Lumbar segmental nerve blocks with local anesthetics, pain relief, and motor function: A prospective double-blind study between lidocaine and ropivacaine. Anesth Analg 2004; 99:496-501.

166. Choi YK, Liu J. The use of $5 \%$ lidocaine for prolonged analgesia in chronic pain patients: A new technique. Reg Anesth Pain Med 1998; 23:96-100.

167. Cucuzzella TR, Delport EG, Kim N, Marley J, Pruitt C, Delport AG. A survey: Conscious sedation with epidural and zygapophyseal injections: Is it necessary? Spine ] 2006; 6:364-369.

168. Kim N, Delport E, Cucuzella T, Marley $J$, Pruitt $C$. Is sedation indicated before spinal injections. Spine (Phila Pa 1976) 2007; 32:E748-E752.

169. Dreyfuss P, Cohen S, Chen AS, Bohart Z, Bogduk N. Is immediate pain relief after a spinal injection procedure enhanced by intravenous sedation? PM $R$ 2009; 1:60-63.

170. Manchikanti L, Giordano J. Re: Kim N, Delport E, Cucuzzella T, Marley J, Pruitt C. Is sedation indicated before spinal injections? Spine (Phila Pa 1976) 2008; 33:1157-1158.

171. Stout A. Discography. Phys Med Rehabil Clin N Am 2010; 21:859-867.

172. Saal JS. General principles of diagnostic testing as related to painful lumbar spine disorders. Spine (Phila Pa 1976) 2002; 27:2538-2545. 